\title{
Article \\ Planning History of a Dutch New Town: Analysing Lelystad through Its Residential Neighbourhoods
}

\author{
Lidwine Spoormans $^{1, *}$, Daniel Navas-Carrillo ${ }^{2}$, Hielkje Zijlstra ${ }^{1}$ and Teresa Pérez-Cano ${ }^{2}$ \\ ${ }^{1}$ Heritage \& Architecture Section, Architectural Engineering + Technology Department, Delft University of Technology, \\ 2628BL Delft, The Netherlands; E-Mails: I.g.k.spoormans@tudelft.nl (L.S.), h.zijlstra@tudelft.nl (H.Z.) \\ ${ }^{2}$ Heritage and Territorial Urban Development in Andalusia Research Group, Department of Urbanism and Regional Planning, \\ University of Seville, 41012 Sevilla, Spain; E-Mails: dnavas@us.es (D.N.-C.), tpcano@us.es (T.P.C.) \\ * Corresponding author
}

Submitted: 29 March 2019 | Accepted: 21 June 2019 | Published: 30 September 2019

\begin{abstract}
This article seeks to analyse the reciprocal influence between the post-war urban planning policies and the development of residential neighbourhoods in Lelystad between 1965 and 1990. This city has been designed 'from scratch' as the urban centre of the IJsselmeer Polders, the largest land reclamation project of the Netherlands. Lelystad's neighbourhood development will be described and contextualised in the Dutch New Towns planning policy (1960-1985), which intended to avoid increasing congestion in the most densely populated area in the Netherlands: the Randstad. Lelystad is seen as a significant case. This New Town exemplifies the evolution in urban planning in The Netherlands in the second half of the twentieth century. Cornelis van Eesteren, who had presided over the CIAM (Congrès Internationaux d'Architecture Moderne) from 1930 to 1947, was responsible for the urban design in 1964, based on the principles of the Modern city and the functionalist design of residential neighbourhoods. However, Van Eesteren was dismissed, and his plan was modified. The successive urban plans, elaborated by the IJsselmeer Polders Development Authority (a public body for the development of the polders), adopted a technical and practical approach, and later moved to functionally integrated neighbourhoods, based on more organic 'Woonerf' theories. The research investigates the relationship between the general and the particular by studying the socioeconomic and political context that conditioned the Dutch New Towns and the specific urban and architectural characteristics of a selection of residential ensembles in Lelystad's neighbourhoods. Furthermore, the research seeks to illustrate the relevance and the influence of both urban planning policies and the effective design of residential configurations.
\end{abstract}

\section{Keywords}

CIAM; Cornelis van Eesteren; Groeikernen; housing ensembles; New Towns; residential configurations; urban design; urban planning; urban theories

Issue

This article is part of the issue "Housing Builds Cities", edited by Luca Ortelli (École Polytechnique Fédérale de Lausanne, Switzerland), Chiara Monterumisi (École Polytechnique Fédérale de Lausanne, Switzerland) and Alessandro Porotto (École Polytechnique Fédérale de Lausanne, Switzerland).

(C) 2019 by the authors; licensee Cogitatio (Lisbon, Portugal). This article is licensed under a Creative Commons Attribution 4.0 International License (CC BY).

\section{Introduction}

A New Town is a town that has not developed organically but was planned and created. The International New Town Institute (n.d.), a platform for research, education, and knowledge exchange for New Towns, gives the following definition:
New Towns are cities or towns that are designed from scratch and built in a short period of time. They are designed by professionals according to a Master Plan on a site where there was no city before. This distinguishes a New Town from a 'normal' city that gradually grows and evolves over time. Also, New Towns are mostly the result of a political (top-down) decision. 
The building of a new city 'from scratch' is a heroic enterprise that challenges the architect or planner to find the ideal shape for the urban program according to the state of the art planning ideas. A New Town is always a reflection of one moment in time and the ambitions of that moment.

This article is about Lelystad, a post-war New Town in the Netherlands. It is presented as an example, among many others, of a New Town development where the reciprocal influence between the urban planning ideals (according to the evolution in 20th-century Dutch urban theories) and the residential neighbourhoods' final execution acquired special significance.

Lelystad is a city located in the polder Oostelijk Flevoland. It is part of the Zuiderzeewerken, the largest land reclamation project of the Netherlands, created between 1930 and 1968. The Zuiderzeewerken included the creation of four polders in the former IJsselmeer: Wieringermeer (in 1930), Noordoostpolder (in 1942), Oostelijk Flevoland (in 1957), and Zuidelijk Flevoland (in 1967). The planned Markerwaard has never been realised. As the creation of new land can be seen in a long tradition of reclaiming land, the foundation of Flevoland's new towns can also be seen in the wider Dutch, and even European, planning policy of the postwar years. In other countries in Northwestern Europe, similar developments took place, such as the New Towns in the United Kingdom and villes nouvelles in France. Although there are important differences in planning policy, culture, and scale of the towns, these programs also aimed at solving the housing shortage in post-war European cities and preventing unrestrained expansion and suburbanisation. As the counterpart of large-scale developments of earlier years like the Grand Ensembles around Paris, they share the characteristic low-rise suburban living environment mainly comprised of singlefamily homes (Nio, 2016, p. 11).

Currently, these cities face new challenges. The energy transition to sustainable sources, which is a main issue all cities have to anticipate, will put pressure on the low-density and car-oriented urban models of post-war New Towns like Lelystad. Moreover, the Dutch Minister of Internal Affairs, concerned with housing policy, expressed the need to build 1 million houses before 2030 . A reoccurring housing shortage, which was the origin of the New Towns, is again relevant in their development.

The historiographical analysis carried out has highlighted wise and poor decisions in the planning and urban development of Lelystad and has generated knowledge that could help upcoming planning policies. Therefore, this article aims to find in the past, that is, in the decision-making processes and urban-residential relationships that underlie the urban development of Lelystad, the keys to understand the present and imagine the future, for Lelystad and other New Towns with similar characteristics.

\section{Method}

The research has been structured in four main phases. The first one focuses on the analysis of the principal milestones that underlie the Dutch New Town planning policy (1960-1985). The second phase seeks to make a synthesis of the historical development of Lelystad based on the successive urban plans that were approved. The next research task has been to find the keys that have defined the growth process of Lelystad through the identification of the residential neighbourhoods and the temporal sequence of its construction. According to the research question, the last phase discusses the possible synergies that have existed between urban planning and the design of housing estates.

The research requires an important search of bibliographical references linking the knowledge generated by other researchers. In addition to the review of research publications or legislative documents, experts on the matter have been consulted. Besides, a continuous consultation of the current and historical planimetry has been acquired, as well as planning documents in several scales. For a study of urban evolution like this, it is essential to work simultaneously with orthographies and images as well as with the geographic information systems available. This process has involved indispensable work of documentary review in different archives. Among them, the Flevolands archive (Het Flevolands Archief) should be highlighted since it has a large part of Lelystad's neighbourhood planning projects. Finally, the detailed analysis of these urban ensembles has required recognition in situ for a better understanding of their evolution. It has been necessary to accompany this process with a photographic and cartographic documentation process.

\section{Dutch New Town Planning Policy}

A series of ministerial memoranda are characteristic for the leading role of the national government on spatial planning in the post-war Netherlands. Large-scale land development planning started with the reclamation of land in the Zuiderzee project and was continued in national plans to cope with reconstruction after WWII. The Dutch national government has had a more significant influence on housing policy than other Western European countries due to subsidy programmes and active land policy, as well as the vast amounts of public domain lands (Faludi \& van der Valk, 1990, pp. 19, 26). In the 1958 memorandum "The Development of the West of the Country" (Werkcommissie Westen des Lands, 1958), the population of the country was projected from 11 million people in 1958 to 13.5 million in 1980 (Faber, 1997, p. 9). This document officially introduced the concept of Randstad to refer to the most densely populated area in the Netherlands (see Figure 1). Horseshoeshaped, it runs from Dordrecht to Utrecht and includes the three largest Dutch cities: Amsterdam, Rotterdam, 
and Den Haag. According to Statistics Netherlands (CBS, 2018), their population in 1960 was 869,602, 729,852, and 606,110 inhabitants respectively.

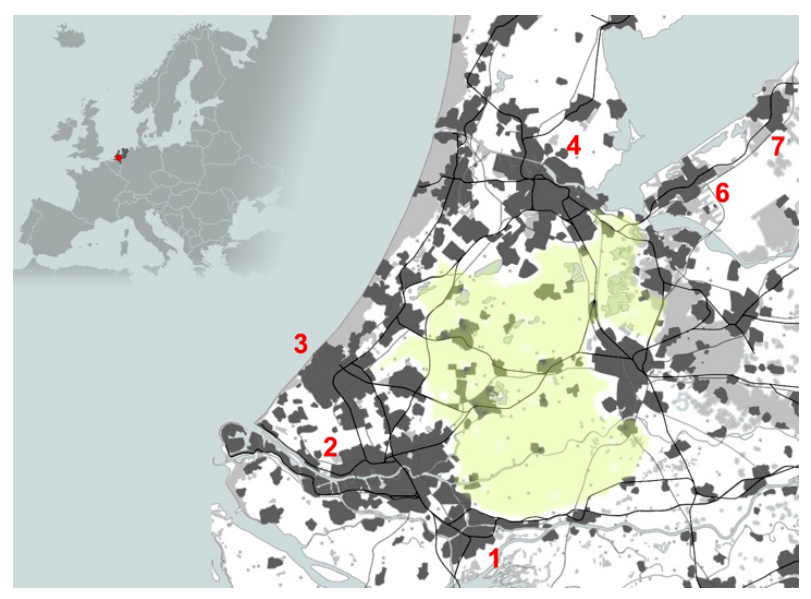

Figure 1. Randstad and Green Heart. Notes: (1) Dordrecht, (2) Rotterdam, (3) Den Haag, (4) Amsterdam, (5) Utrecht, (6) Almere, and (7) Lelystad. Source: authors.

To regulate the problem of overcrowding and congestion, it was proposed to keep buffers open between towns and cities, preserve a central open area, Green Heart (Groene Hart), and concentrate urbanisation in a limited number of locations elsewhere in the country. In 1960, the First National Spatial Planning Policy document sketched out an outwardly-focused model for growth for the Randstad around the central open area. It can be considered as an archetypical example of a polycentric metropolis (Maas, 2012 , p. 7). Existing small or medium-sized cities were to be expanded and even new cities could be introduced to accommodate the 'surplus' of inhabitants of the big 'donor' cities. These overflow cities should grow to independent cities and house 50,000 to 100,000 people each. They were suggested close to the Randstad to prevent high commuting traffic costs (Pantus, 2012, p. 18). This was the kick-off for the Dutch New Town planning policy.

In the Second National Spatial Planning Policy document of 1966, things became more urgent. The growth of prosperity and population was expected to be stronger than assumed in earlier plans. The Dutch population reached twelve million in 1965. That same year, Statistics Netherlands (Het Centraal Bureau voor de Statistiek) predicted 21 million inhabitants in the year 2000 (Pantus, 2012, p.18). Furthermore, cities in the Randstad were expanding, which was seen as inconsistent with the concept of 'Green Heart' of the 1960 Spatial Planning Policy document. Therefore, more attention was needed for the possibilities of combining the benefits of urban life and a quiet residential atmosphere. A new concept was introduced: bundled de-concentration. This was the happy medium between concentration in large metropolises and total de-concentration as urban sprawl. The Blokjeskaart accompanied the Second National Spatial Planning Policy Document. Yellow, orange, red, and brown blocks on this map represented four types of urbanisation (A, B, C, D) and indicated how 20 million inhabitants could be housed in the year 2000 in diverse living environments, ranging from village environments to cities (see Figure 2). The coloured blocks indicate the location, size, and a density between 15 and 60 dwellings per hectare. This type of map showing blocks was innovative and would become influential in Dutch urban planning in later years (Maas, 2012, p. 18).

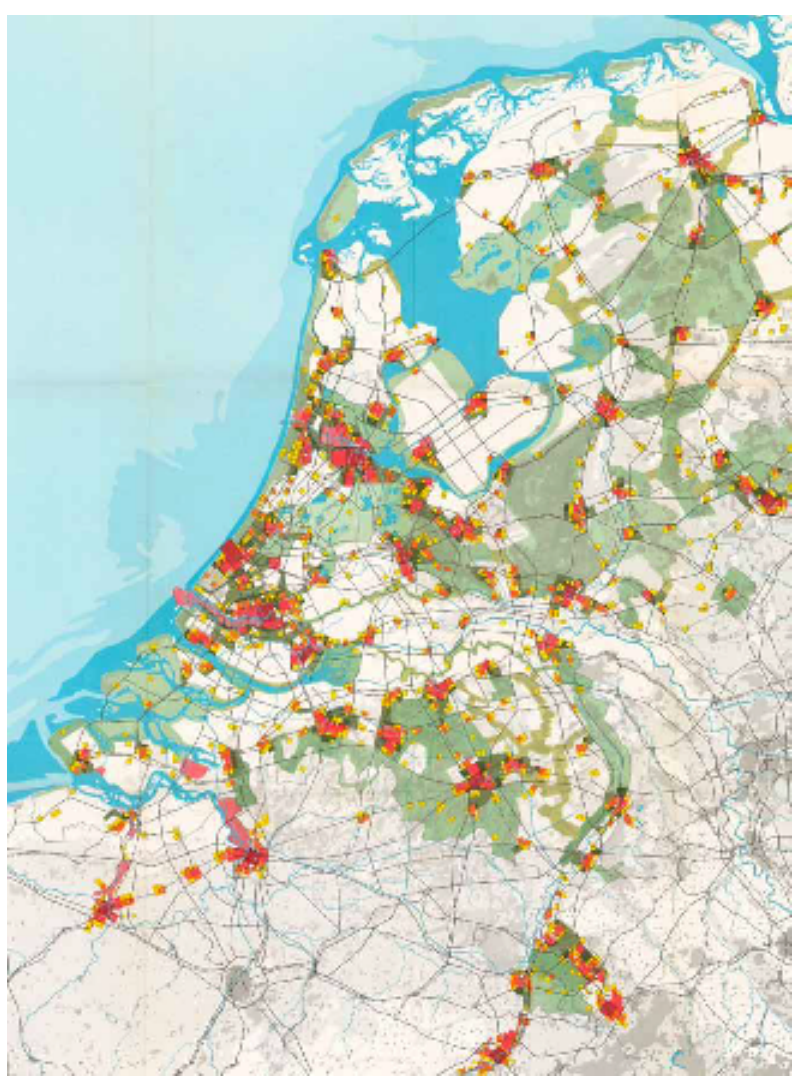

Figure 2. Blokjeskaart in 1966. Notes: Type A in yellow $(5,000$ inhabitants), type $B$ in orange $(15,000$ inhabitants), type $C$ in red (60,000 inhabitants), and type $D$ in brown (250,000 inhabitants). The first urbanisation type had local bus service, while the rest had a railway station and intercity bus or express train service (Maas, 2012).

Contrasting to the Second, in the Third National Spatial Planning Policy document of 1974 , the expected population growth for the year 2000 shrank to 16 million. But the strategy of bundled de-concentration was continued and elaborated in this document. The term Groeikern (growth centre) was introduced and defined as: "a Groeikern is a nucleus that should experience strong growth, especially for the benefit of a nearby (larger) city, in case this growth is exceptional compared to the size of the nucleus itself" (Faludi \& van der Valk, 1990, p. 96, emphasis added). The relation between the older and bigger 'donor' city and the appurtenant Groeikern, was delicate. They should be independent, but not compete with the donor city. On the one hand, the Groeikern should not affect the development of the central functions of the 
big city. On the other hand, they should not turn into a dormitory suburb and include facilities, services, and generate employment to not depend entirely on the donor city. In a few stages, the following cities were appointed as Groeikern: Purmerend, Hoorn, Alkmaar, Lelystad, Huizen, Almere, Zoetermeer, Spijkenisse, Hellevoetsluis, Nieuwegein, Houten, Capelle a/d IJssel, Duiven-Westervoort, Helmond, Hoofddorp, Hoekse Waard, Leusden-Hamersveld, Pijnacker-Nootdorp, and Barendrecht-Smitshoek. Except for Almere and Lelystad, the origin of these growth centres was a small village. So, strictly, Lelystad and Almere are the only new towns being developed on new land. However, all of them were appointed and planned (from scratch) to constitute a new territorial system based on new urban centres. Tasks for every city were defined in terms of location, number, and time planning. By listing names and numbers, the 1972 document made a practical and instrumental start to the planning policy. As written by the authors: "after the 'brain and soul' (first), the 'flesh and blood' (second), now the Spatial Planning Policy has got "hands and feet"' (Faludi \& van der Valk, 1990, p. 96)

The Dutch New Town planning policy has been very successful in assessing the number of built dwellings. After a laborious start in the period 1972-1979, when, because of municipal organisational reasons, for example, the production of dwellings, employment, infrastructure, and social-cultural facilities was behind schedule, in the period 1979-1985, almost all Groeikernen had fulfilled or gone beyond their growth task. From 1972 to 1985, 1.6 million dwellings were built in The Netherlands, of which ca. 182,000 (11.3\%) in a Groeikern. This has made an enormous contribution to solving the post-war housing shortage (Faber, 1997, pp. 1, 58, 62). Moreover, the strategy of bundled de-concentration has successfully protected the Green Heart from overbuilding. The Groeikernen served the green areas and the cities. Housing the overspill of their population enabled the donor cities to renew their old inner-city neighbourhoods. The 1983 memorandum "Outline for the Urban Areas" included a preference for new developments at shorter distances to the donor city. Lelystad loses the Groeikernstatus, but Almere continues expanding.

\section{Cornelis Van Eesteren and the CIAM}

In 1916, after the successful reclamation of De Beemster and De Haarlemmermeer, the first plan was made for the reclamation of the Zuiderzee. These IJsselmeer polders were primarily intended for agricultural purposes but could, in addition to recreation, also offer a solution to address the pressure on large cities to offer more housing. The Dutch Institute for Housing and Urban Planning (1925-1933) examined the possibilities (Hemel, 1994, pp. 30, 45). During the planning stage of the first polders in the Zuiderzee, the Wieringermeer and the Noordoostpolder, opposing visions played a role. M. J. Grandpré Molière, who was the protagonist of the traditionally-oriented Delft School was responsible for the aesthetics, later succeeded by S. J. van Embden. T. K. van Lohuizen represented the Modern Movement and was responsible for urban design. In 1929, the report The Future Landscape of the Zuiderzee Polders presented the first overall plan for the polders in the former Zuiderzee. From 1942, Cornelis van Eesteren became involved in the development of the IJsselmeer polders. Consequently, the ideas of The Modern Movement and the CIAM (Congrès Internationaux d'Architecture Moderne) became leading ideas.

In parallel to the reclamation plans for the Zuiderzee, an expansion plan for Amsterdam was initiated in 1921. The Public Works Department (De Dienst der Publieke Werken) and the Urban Development Department (Afdeling Stadsontwikkeling) were established in 1928. Van Lohuizen was appointed deputy director of Public Works Department and Van Eesteren was the director of the Urban Development Department in Amsterdam from 1929 to 1959 (Hemel, 1994, p. 46). Van Lohuizen and Van Eesteren have cooperated on the General Extension Plan (Algemeen Uitbreidingsplan, AUP) of Amsterdam (see Figure 3). This was completed after a number of steps in 1934 and approved in 1939 by the official implementation agencies. In 1939, the first constructions started in the Bos en Lommer/Landlust. Their linear blocks around a semi-public courtyard were an innovation compared to the earlier perimeter city blocks. The AUP is characterised by urban patterns of buildings and ensembles in open urban blocks and a strict division of functions in living, working, recreation, and transport. Public greenery and water formed the structuring urban elements, the starting points for the later CIAM principles.

Van Eesteren was closely involved with CIAM from 1928 to 1960 . He became president in 1930 on the recommendation of W. Gropius. The first plan for the expansion of Amsterdam from 1931 was discussed at the fourth congress of the 1933 CIAM in Athens. The Dutch CIAM members, including Van Eesteren and Van Lohuizen, were closely involved in the preparations for this congress. At the request of Le Corbusier, Gropius, Steiger and Giedion, their research "The Functional City" was elaborated into "The Athens Charter", the ultimate guideline for the design principles of the CIAM (Somer, 2007 , p. 86). The implementation of the AUP came to a halt at the beginning of the Second World War but planning on a national scale continued.

\section{Lelystad's Urban Planning}

In 1942, the Zuiderzee Works Department decided that a detailed urban plan was needed for the IJsselmeer polders, such as the AUP for Amsterdam. Van Eesteren was asked to take on this task. In 1933 Van Eesteren had visited De Wieringermeer polder in a CIAM context. He had been inspired by the result of the Wieringermeer and was particularly impressed by the coherency of the de- 


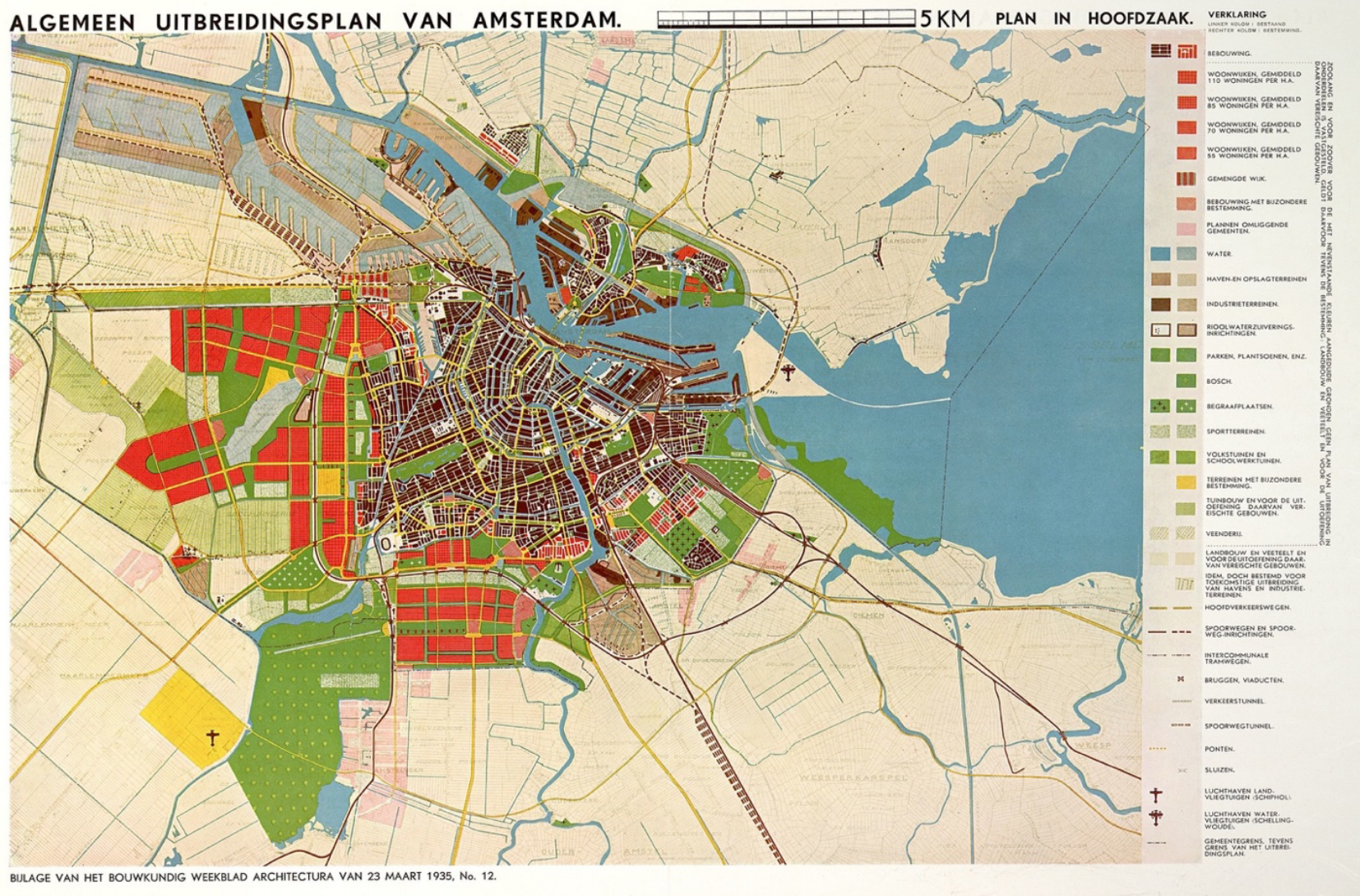

Figure 3. AUP of Amsterdam in 1935. Source: Amsterdam archive image bank.

sign, the regularity of systems and the rectangular patterns (Hemel, 1994, p. 151).

In 1958, Van Eesteren was commissioned by the National Office for the IJsselmeerpolders (Rijksdienst voor de IJsselmeerpolders, RIJP) to design the urban plan for Lelystad, which was to become the urban centre of the IJsselmeer Polders. The design initially allowed for 50,000 inhabitants, with the possibility to grow to a total of 100,000 . The issue of phased growth would become a problematic aspect for Van Eesteren's plan (Brouwer, 1997, p. 24). Already in 1949, Van Eesteren had worked on the urban plan for Lelystad. In the first designs for the 'ideal' city of the 20th century, the centre was positioned in a bay and elevated to the level of the dyke. The creation of a strong city silhouette would form a 'crown' for Lelystad as the polder capital, relating to Bruno Taut's Stadtkrone (Hemel, 1994, p. 177). It can be regarded as the expression of the artist/urbanist Van Eesteren. However, his ideas about the location at the waterfront and the raised ground level of the centre were not accepted. In Van Eesteren's final design, presented after many adjustments in 1964, the city centre is east-west oriented, located south of the main road leading westward to the planned polder of Markerwaard. The infrastructural plan combined elevated main roads with a separate system of secondary streets at ground level. Neighbourhoods were planned on both sides of the centre (see Figures 4 and 5).

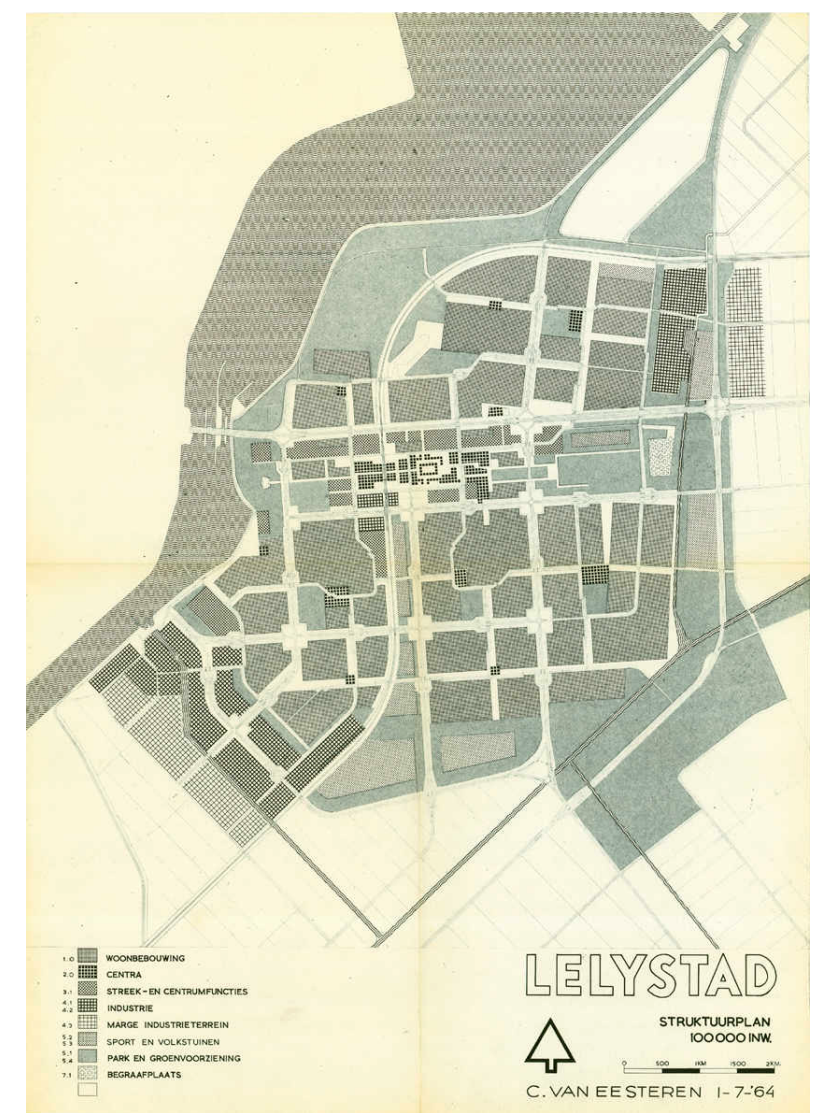

Figure 4. Van Eesteren's structure plan, July 1964. Source: Flevolands archive. 


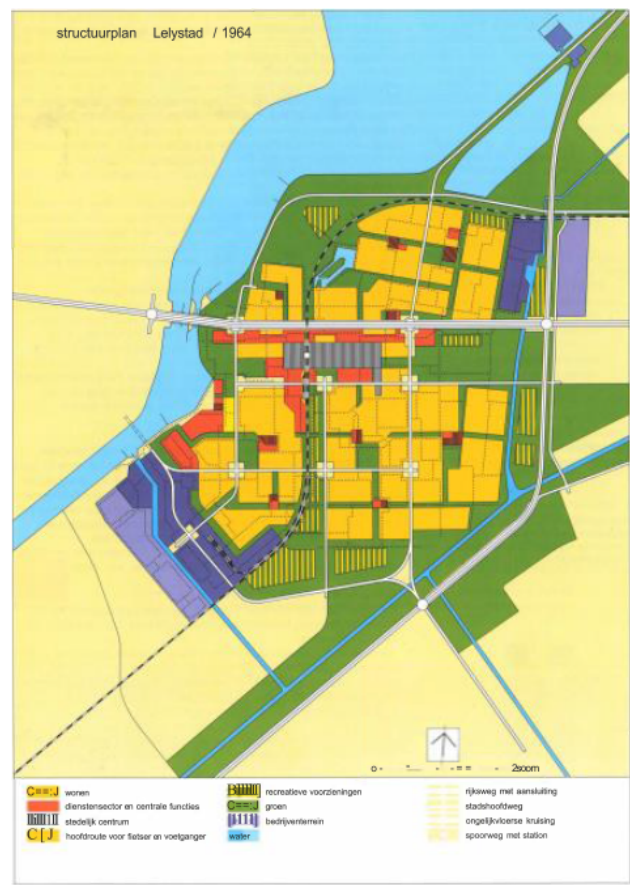

Figure 5. Structure plan 1964 (see also Figure 4).

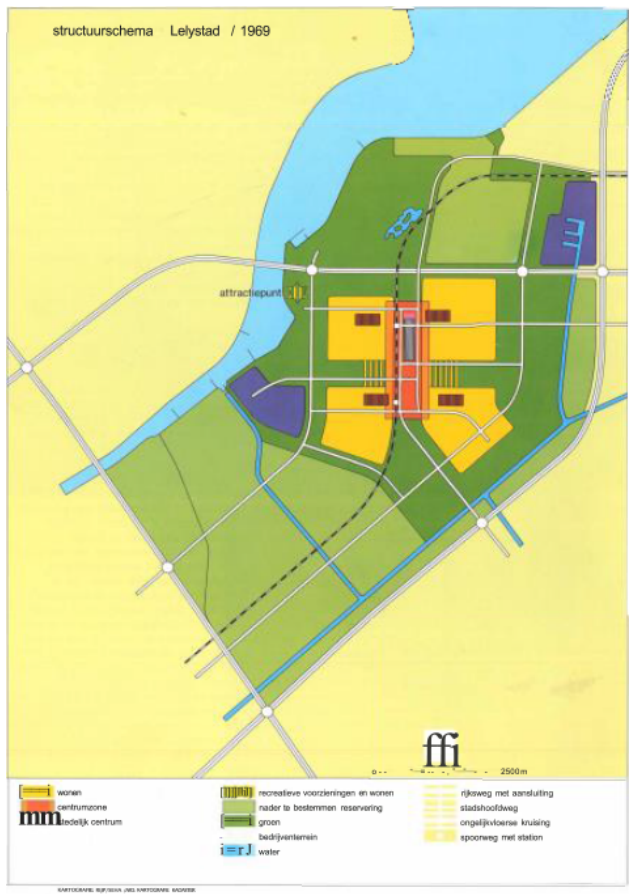

Figure 6. Structure scheme 1969.

But because of major disagreements regarding the urban design and planning process, Van Eesteren's plan was rejected in mid-1964 by the Planning Committee (Planologische Commissie) and Van Eesteren was set aside in early 1965 . The main argument was the continuous growth to 100,000 inhabitants that this plan assumed, which was thought improbable by the authorities (Brouwer, 1997, p. 49). Although Van Eesteren was dismissed, the construction of the first neighbourhood was started in 1966, according to his plan. The
Zuiderzeewijk included dwellings, parks, a school, green structures, and a commercial centre. However, Van Eesteren's infrastructural system was reversed and therefore cheaper: main roads at ground level and slow traffic crossing by bridges. For a long time, nothing was published about the plan for Lelystad. Pierre Merlin, director of the Institute d'Urbanisme in Paris, described it in 1972 as a plan in which the general principles of the CIAM, based on the functional city, are recognisable (Hemel, 1994, p. 255).

In need of a more flexible development plan, the authorities commissioned the urban advisors De Bruijn, Van Embden and Kuiper to set up their "structure scheme" (1969; see Figure 6). This scheme allowed for an open planning process and phased growth by complete self-sufficient neighbourhoods. Different from Van Eesteren's functionalist ideals, the leading principle was the Wijkgedachte (the neighbourhood unit), based on Clarence Perry's neighbourhood unit theory. The plan consists of four self-contained neighbourhoods around the city centre. This centre was north-south oriented now, and able to expand southward towards Randstad. Van Eesteren's ideal design was replaced by pragmatism (Brouwer, 1997, p. 93). Later, the structure scheme (Figure 6) developed into a structure plan (1978; see Figure 7). Based on the same principles, the plan included some reconsideration. Instead of the former district centres attached to the central zone, all commercial and societal functions were concentrated in a main central zone. A lower density resulted in more expansive residential areas (Constandse, 1980, p. 67). The railway in the central zone had been planned from the start but was only delivered in 1988.

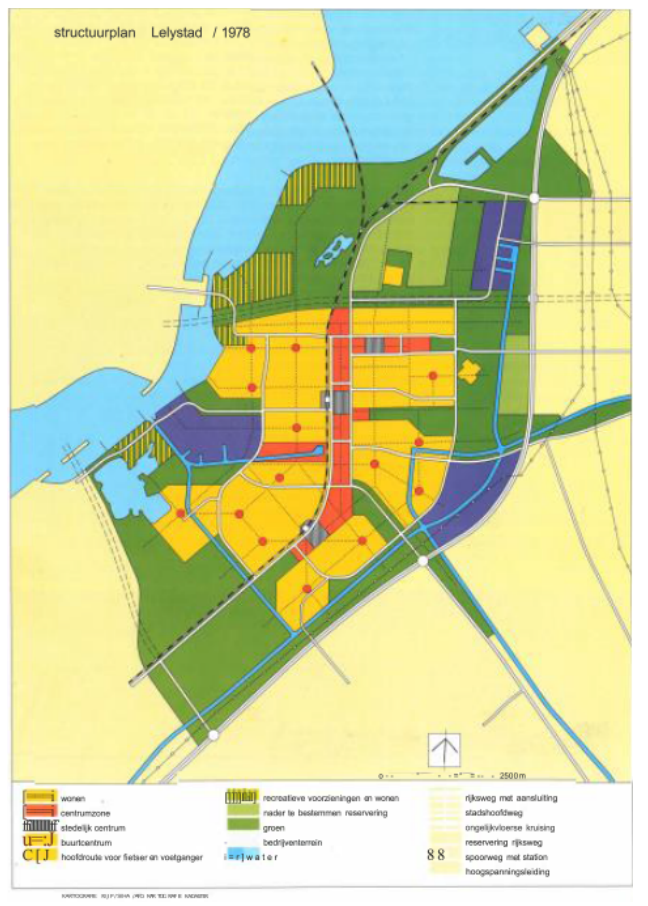

Figure 7. Structure plan 1978. Source: Constandse (1980) 


\section{Lelystad's Neighbourhood Development}

During the planning and construction of the Dutch New Towns, there was a rather sudden turnaround of ideals, described by De Vreeze:

Until 1972, the high-rise was dominant, surrounded by long straight blocks of multifamily houses and terraced houses, following the tried and tested schemes of the successive collections of standard floor plans. Then suddenly, in every neighbourhood or even every street, an enormous variation appears in the composition of housing types, the form of streets and squares, planting schemes, the shape of building blocks, facades and materials, but predominantly low-rise! (de Vreeze, 1993, p. 406)

This movement was strongly influenced by the Forumgroup of architects, under the inspiring leadership of Aldo van Eyck. As the new board of Forum-magazine in 1959, they accused architects and planners of making The Netherlands 'unliveable' and pleaded for a new architecture that would create 'liveable cities' and coherence between people and things (van Heuvel, 1992, p. 12). Although generally influential in the architectural climate of that time, it was especially in this suburban environment of the Groeikernen that the new architectural and urban design of the Forum group could prosper (de Vreeze, 1993, p. 405). Important and innovative themes were flexibility, participation, shelter, appropriation, the 'in-between', duo-phenomena, industrial production, and interconnected repetitive structures.

In later stages of the Groeikernen development, leading design ideas changed again. In 1979, the urbanist and architect Carel Weeber advocated the rehabilitation of an urban discipline that was autonomous, based on formal principles, ordering the urban space mainly by two-dimensional compositions, and when financial support for Groeikernen was reduced in the 1980s, Weber's plea for simple straight-line urban structures suddenly received a great deal of support in practice (de Vreeze, 1993, p. 407).

The research has identified that these two general transitional moments in urban and architectural Dutch planning have clear influence in our case study. This fact allows us to divide the analysis of Lelystad's neighbourhood development into three phases that will be described in the following paragraphs.

\subsection{First Phase: Orthogonal-Structure Neighbourhoods in the 1960s}

The urgency to start developing housing led to the planning of the first neighbourhood by Governmental request, before the official dismissal of Van Eesteren's plan (Brouwer, 1997, p. 52). This early urban development was to house the first 4,800 dwellings, in addition to the central services and infrastructure for the first 17,000 in- habitants of the city (Geurts, 1995, p. 63). It is located south of the main road and protected by a large tree screen. This first district (Wijk 1 ) is made up of two neighbourhoods, located respectively north and south of the central area (currently called Lelycentre) which was to be comprised of commercial premises, offices, and other community services for the first inhabitants of the city.

Following a rational and orthogonal layout, based on the neighbourhood-unit, the design sought to create an attractive living environment and generate a certain urban complexity by avoiding excessive dispersion and concentrating urban uses. Paradoxically, it was planned with a density of approximately 30 dwelling units per hectare, significantly higher than other residential areas of the polder. Both Van Eesterens' plan and the later Structuurschema had supported high-rise buildings, especially in the residential areas near the centre. However, the RIJP would defend low-rise construction based on the population's interest in living in single-family homes and, therefore, their opposition to high-rise buildings (Constandse, 1989, p. 45).

The construction of the first houses began in March 1966 in the north of Wijk 1. The Zuiderzeewijk is an area of approximately 71 hectares and about 1600 houses, of which 200 units are apartments (12.5\%). Most of these flats are located in three-storey buildings with gallery access on the first and second floors. The communal storerooms and garages and some small dwellings are on the ground floor. The majority of the residential units are single-family row houses $(87.5 \%)$ that respond to three different architectural designs (see Figure 8). The first are called 'drive-in' houses, with a garage on the ground floor. The kitchen and living room are on the first floor and the bedrooms on the third floor.

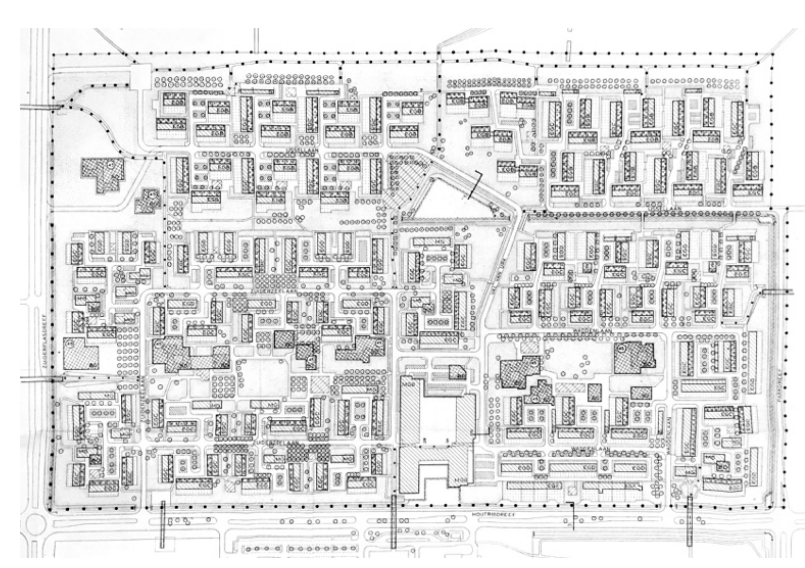

Figure 8. Zuiderzeewijk's urban layout. Source: Flevolands archive.

The second type is called 'piano house' due to its section design (see Figure 9). The kitchen and living room occupy the ground floor, the bedrooms are on the first floor, and the second floor is set back, generating an outdoor terrace. The third is a two-story type that can be considered as a variant of the previous one. Despite the low density of the neighbourhood, all dwellings were initially 


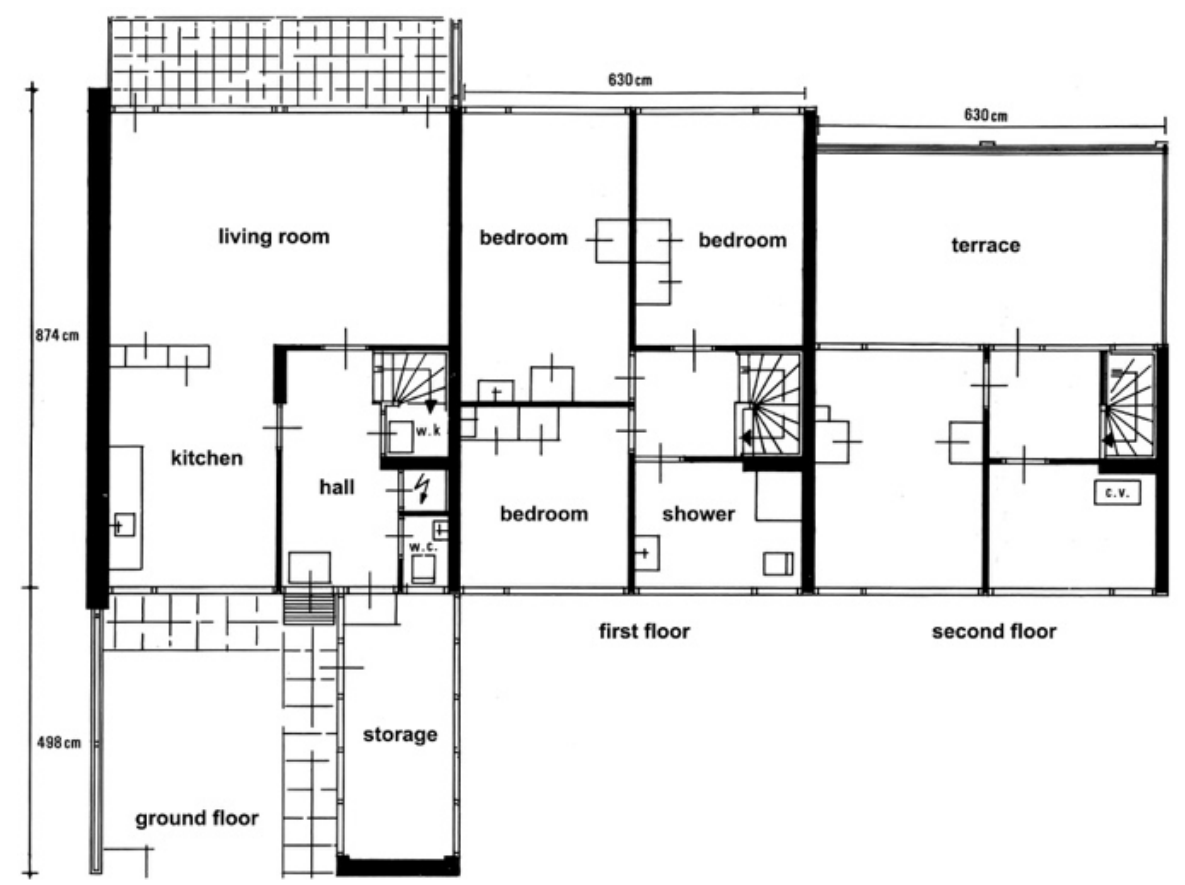

Figure 9. Zuiderzeewijk's piano house's floor plans. Source: Flevolands archive.

designed with flat roofs. This fact gives it a modernist urban character. Likewise, all of the houses are grouped around an area conceived for car parking. These areas are accessed through slow traffic roads that respond to a rational and hierarchical mobility design. A large eastwest green zone was planned in the neighbourhood core, where different facilities would be placed, mainly schools and a large apartment complex called Rode Klif.

The first houses south of the shopping centre were built in 1968. The Atolwijk was designed to house 5,300 dwellings (see Figure 10). The 165-hectare western area would initially be reserved for the construction of higherdensity buildings close to the new centre and the northeastern boundary for the development of detached houses. The central area would repeat the previously used residential types (see Figure 11). Apart for the dwellings located in front of the shopping centre, which are apartment blocks (2\%), most of the neighbourhood is made up of single-family dwellings (98\%). In this case, the houses are not gathered around parking lots, but

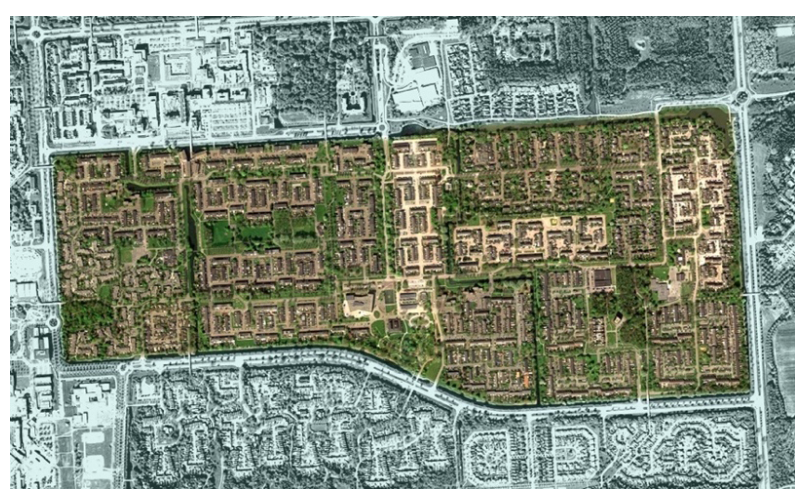

Figure 10. Atolwijk: aerial map. Source: authors. around internal circular roads which facilitate direct access to all the neighbours. In general, the two-storey row houses are in the interior of these ensembles, and the three-storey row ones on the perimeter. The pedestrian paths, courtyards, and open areas are located on the other side. Unlike the northern zone, the different school and sports facilities will be grouped to generate different community centres or meeting points throughout the neighbourhood.

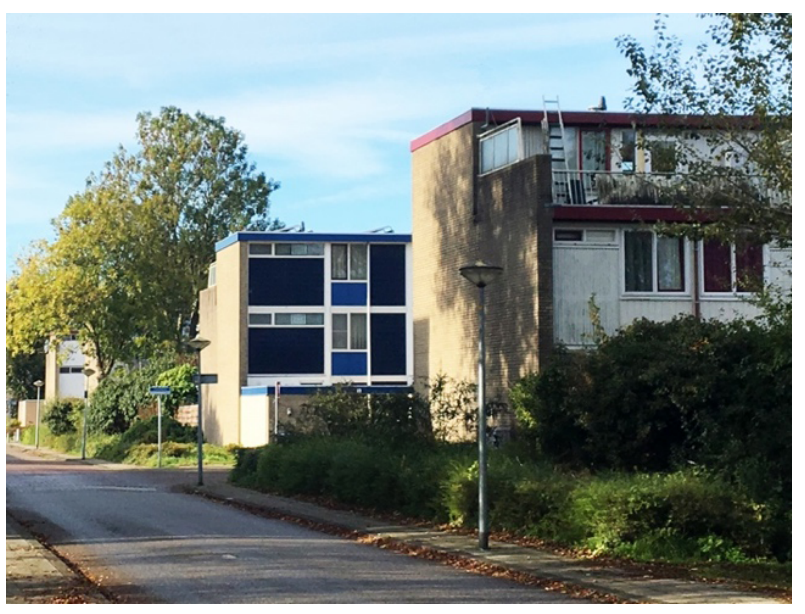

Figure 11. Atolwijk: view of 'piano' houses. Source: authors.

Although Atolwijk's urban design is aligned with the rationality of modern planning, the constructive development of its dwellings introduced a differential vector that somehow anticipated the coming change in neighbourhood design. In 1970, the RIJP allowed building sloped roofs. Until this moment, the housing construction in 


\section{COGITATIO}

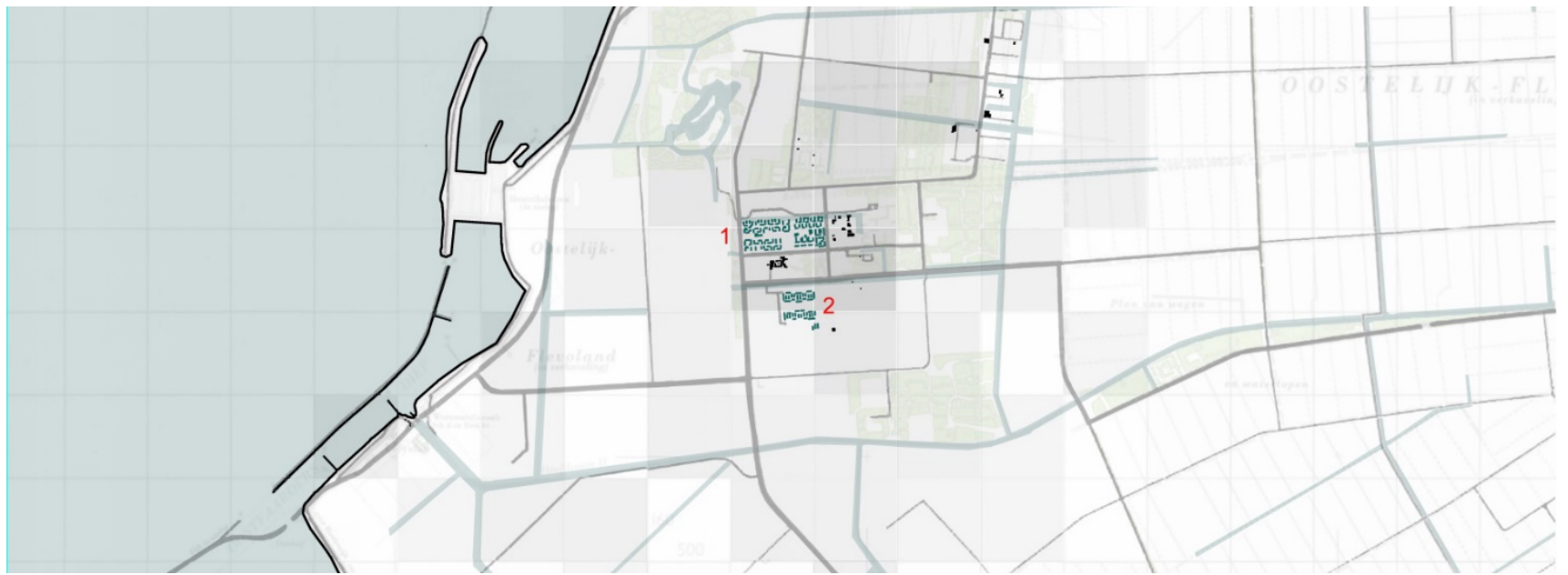

Figure 12. Neighbourhoods that had been built in 1970. Notes: (1) Zuiderzeewijk (phase 1) and (2) Atolwijk (phase 1). Source: authors.

Lelystad was the responsibility of this public agency, which commissioned private architects and contractors to design and build the homes. However, they should operate under the supervision of RIJP. Not only the new structures would be affected, existing flat-roofed buildings would also be replaced by pitched roofs (Heeger, 1992 , p. 35). Currently, this fact is noticeable in many of the piano houses. The first family settled in Lelystad in October 1967. By January 1968, 120 families had moved in and 1,200 by the end of 1970 (see Figure 12). In 1971 a total of 1,744 dwellings had been built: 263 'drive-in' houses, 901 'piano' houses, 441 two-storey row houses (171 sloped-roofed ones), 10 one-storey homes (2 sloped-roofed ones), and 129 apartments (RIJP, 1971, p. 124).

\subsection{Second Phase: Organic Urban Form and Flexible Planning Process}

According to population growth forecasts, RIJP deemed that it was necessary to start planning Wijk 2 before completing Wijk 1 (RIJP, 1975, p. 19). This new district would be located west of the new central zone planned in the Structuurschema. The urban plan would replace the district centres with smaller neighbourhood nodes. The aim was to promote the development of this new north-south central axis. Likewise, the limits of this second development area would extend towards the north and west. This extension allowed to maintain the foreseen number of houses $(7,000-8,000$ units), although the density was reduced. The result is a 900-hectare district divided into five areas or subzones.

The north zone, made up of the neighbourhoods of Karveel and Boeier, is separated from the main road by a large green screen that had been included in the Structuurschema. Close to the new city centre in the central zone, Kempenaar, Kogge, Gondel, and Schouw were conceived as 'villages' around a large car-free park (see
Figures 13 and 14). To the East, we found Punter, Jol, and Galjoen. The littoral zone was reserved for a small residential complex and a leisure area, currently occupied by a shopping centre and a city museum. In the southeast end, we found Schoener, Botter, Tjalk, and Landstrekenwijk. An industrial estate holds the fifth zone in the southwest end.

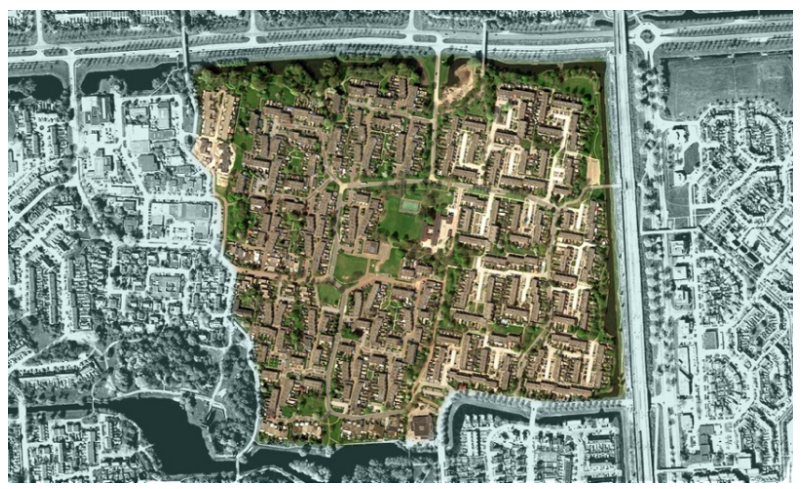

Figure 13. Kempenaar: aerial map. Source: authors.

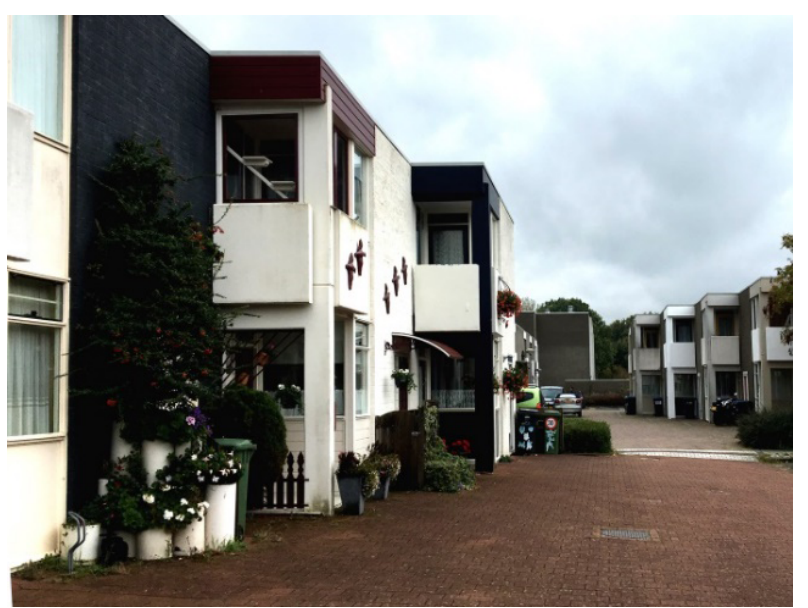

Figure 14. Kempenaar: view of staggering houses. Source: authors. 
The development of the district, although partially designed by different architects, was supervised by RIJP's planners (van der Wal, 1997, p. 176). The residential areas, although physically separated by the main city roads, share specific urban and architectural characteristics. Except for the littoral zone, these neighbourhoods, with approximately 400-600 dwellings, would be designed with semi-detached houses endowed with a courtyard (see Figures 15 and 16). The construction of apartments was abandoned. As in previous cases, houses are grouped around a community and parking area. Nevertheless, in some of the neighbourhoods, this open space was replaced by a street which had the same function. Following Radburn's principles, priority would be given to pedestrians within the residential areas, encouraging bicycle lanes and pedestrian paths.

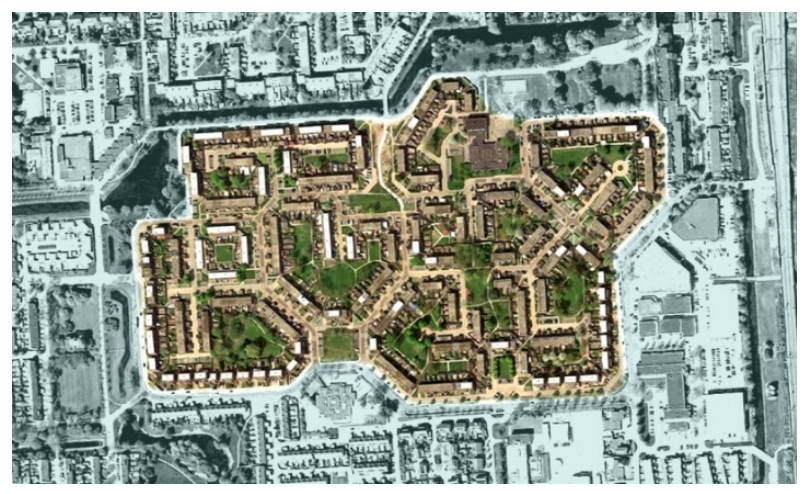

Figure 15. Tjalk: aerial map. Source: authors.

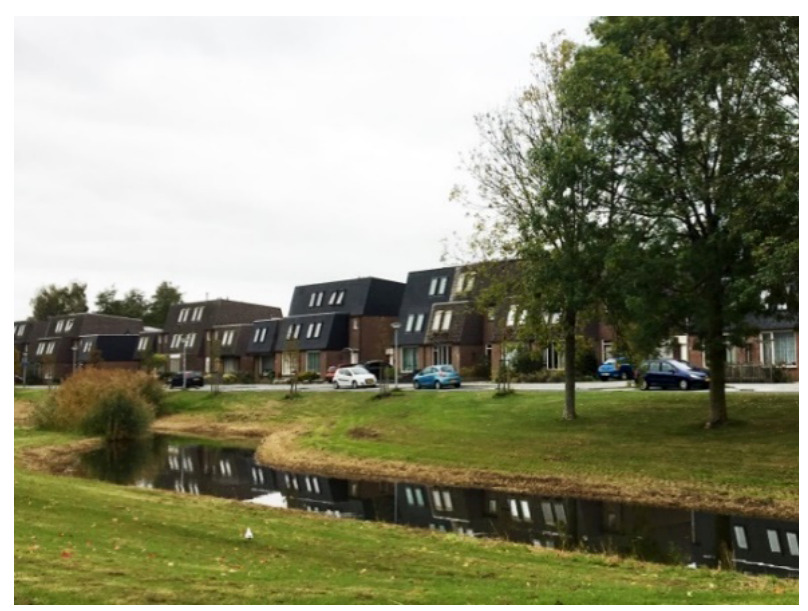

Figure 16. Tjalk: view of row houses. Source: authors.

The design of these neighbourhoods would seek to break with the monotony produced by the orthogonal layout of the 1960 s to generate a unique spatial experience. Moreover, it would provide shelter, appropriation, and collective space, as well as a shared urban image that would allow residents to identify themselves with the neighbourhood. This transition was gradual. The first housing ensemble built in the neighbourhoods of Kempenaar would maintain the orthogonal design of Wijk 1 , as well as the flat roofs, but introduce a slightly diagonal direction (see
Figure 17). In the second phase of this same neighbourhood, the alignment of the facades is broken by staggering the dwellings (see Figure 14). Furthermore, Kogge follows a radial layout with semi-detached and sloperoofed houses.
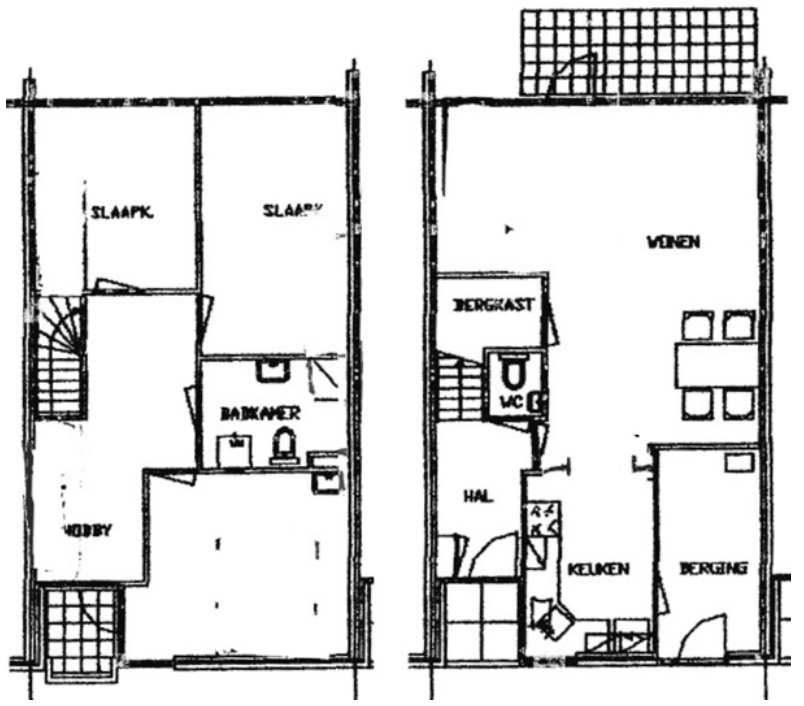

Figure 17. Kempenaar's house plans. Source: Flevolands archive.

The development of neighbourhoods such as Jol, Tjalk, Galjoen, or Botter, and also Archipel (Wijk 4), were a decisive step in the transition from orthogonal patterns towards organic schemes close to Woonerf (residential zone in which slow traffic has a priority over motorised traffic) theories. These examples are made up of large groups of dwellings describing roughly circular and non-geometric shapes where car access is limited (see Figure 18). The meandering street patterns are more complex than in previous cases, being "reached by a road that provides access to several of them and that is subordinated to them" (Wagenaar, 2015, p. 493) They share many of the morphological and pathological features with the so-called bloemkoolwijk ('cauliflower' neighbourhoods, with organic urban structures).

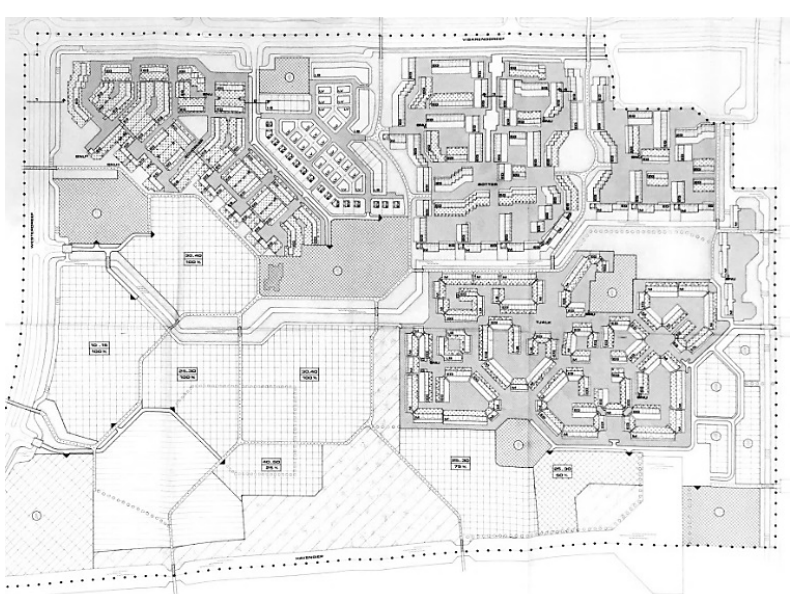

Figure 18. Botter and Tjalk's urban layout. Source: Flevolands archive. 


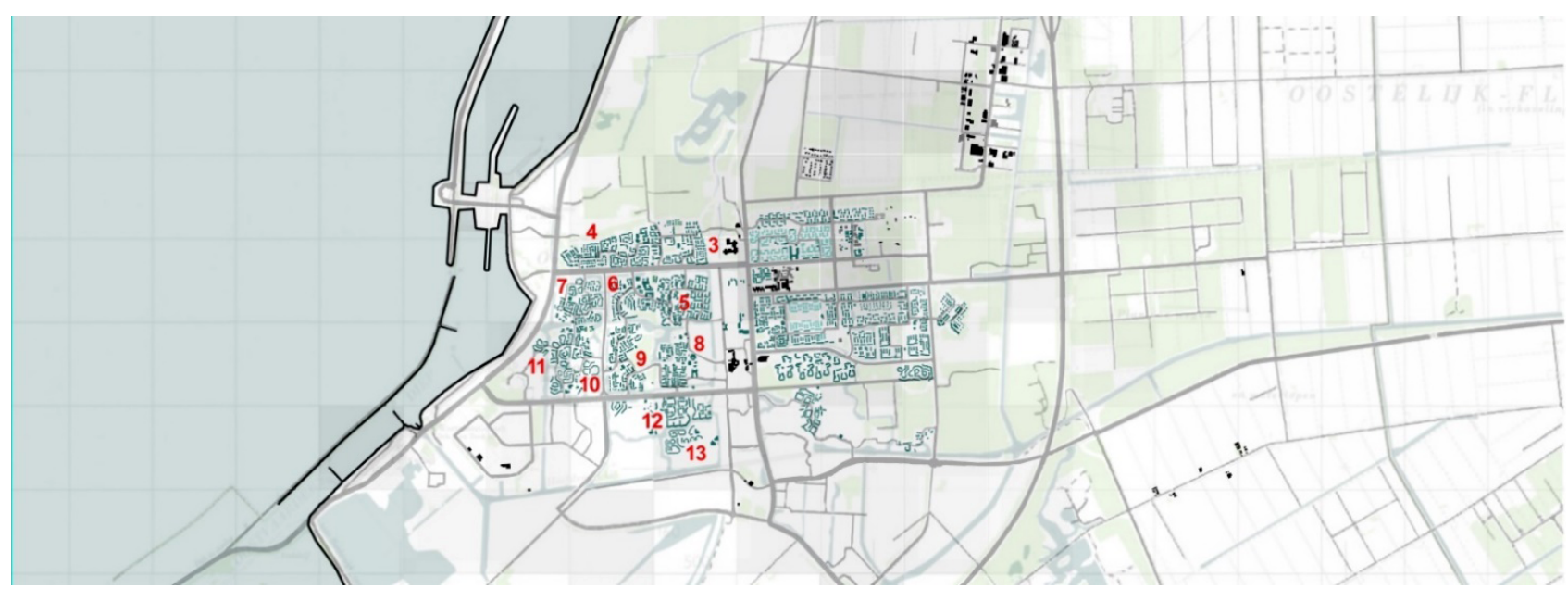

Figure 19. Neighbourhoods that were built between 1970 and 1980. Notes: (3) Karveel, (4) Boeier, (5) Kempenaar, (6) Kogge, (7) Punter, (8) Schouw, (9) Gondel, (10) Jol, (11) Galjoen, (12) Boswijk (phase 1) and (13) Tjalk. Source: authors.

This process coincides with the set-up of the Housing Development Foundation (Stichting Woningbouw Lelystad, SWL) in 1972. This public housing foundation was created as an intermediate solution between direct promotion and the housing-association model due to the government's desire to eliminate ministerial spending on housing. In addition to government subsidies for housing promotion, this organisation could be financed with capital market loans guaranteed by the Ministry of Public Housing and Spatial Planning (van Woensel, 1995, p. 22). The SWL was to assume the functions of the RIJP. However, it took charge of the project management for the first two years and did not achieve financial autonomy until 1974. It was at that time that there was an exponential growth in housing construction in Lelystad with the development of neighbourhoods of up to 700 dwellings (see Figure 19).

The high number of dwellings promoted by SWL would lead to an increase in the construction rate of private houses (Geurts, 1993, p. 76). According to the Annual Statistical Summary of Lelystad, 3,260 residences (330 private ones) were built from 1967 until 1973 while 1,118 dwellings (434 private ones) were built in 1974 (Gemeente Lelystad, 1987, p. 65). Although the 1974 National planning document reduced the need for housing, the construction rate continued to grow until 1977, when the number of private houses (985) exceeded those developed by the SWL (890). In that year, the functions of the SWL would be assumed by two housing associations: the SWL and the Christian Housing Foundation (Christelijke Woningbouwvereniging) De Opdracht (van Woensel, 1995, p. 26).

\subsection{Third Phase: Returning to an Orthogonal Layout}

The third of the districts (Wijk 4) is located to the east of the new urban centre and to the south of Wijk 1, separated by a green buffer zone. The district is divided by one of the main roads into two zones. The urban plan for this area includes earlier developments, such as the previously mentioned Archipel, but was approved in 1976.

The size of the district, approximately 370 hectares, made it unfeasible to consider it as a single residential unit. On the other hand, the neighbourhood size tested in Wijk 2 had proved insufficient to reach the necessary social cohesion to build a real neighbourhood community. These reasons led to the division of the district into larger neighbourhoods of 1,500-2,000 families, with an approximate density of 35 units per hectare. Each of these neighbourhoods, Boswijk, Waterwijk, and De Landerijen, has shops, schools, social facilities, and other primary services at a maximum distance of 100 meters from all houses (see Figure 20). In our opinion, this approach seeks to recover the urbanity lost in the second phase by the reintroduction of facilities and proximity that foster neighbour relations. However, it does not renounce the benefits of being surrounded by a natural surrounding (albeit artificial). Again, the Garden City ideals were used to unite the best of urban and rural environments.

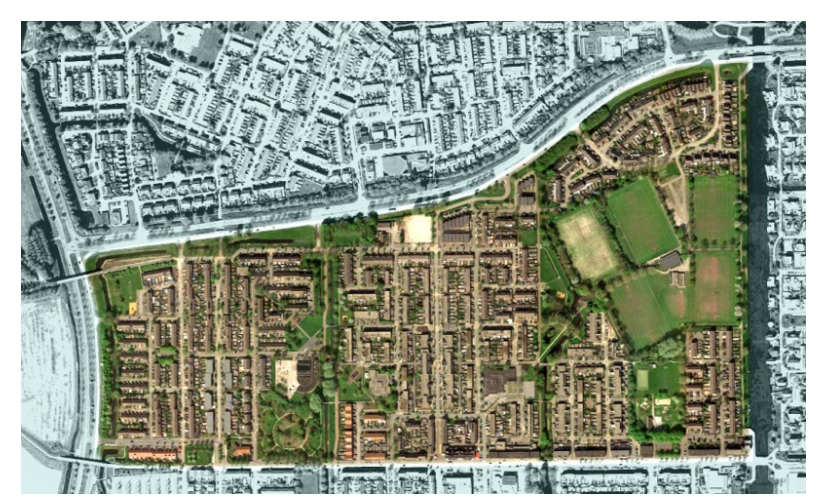

Figure 20. Waterwijk (phase 1): aerial map. Source: authors.

Many of these ideas were at the base of the Structure Plan, which was being developed at the same time 
(see Figure 7). Although it was approved in 1978, the Structure Plan had been used since the beginning of 1975 (van der Wal, 1997, p. 181). This new plan emphasised the central zone, which was to become a connecting element among the different districts. At the same time, it promoted neighbourhood nodes according to the characteristics described above. Besides, the plan clearly distinguished the central axis which should be characterised by an urban image, as opposed to residential neighbourhoods characterised by their low density (approximately 20 dwellings per hectare).

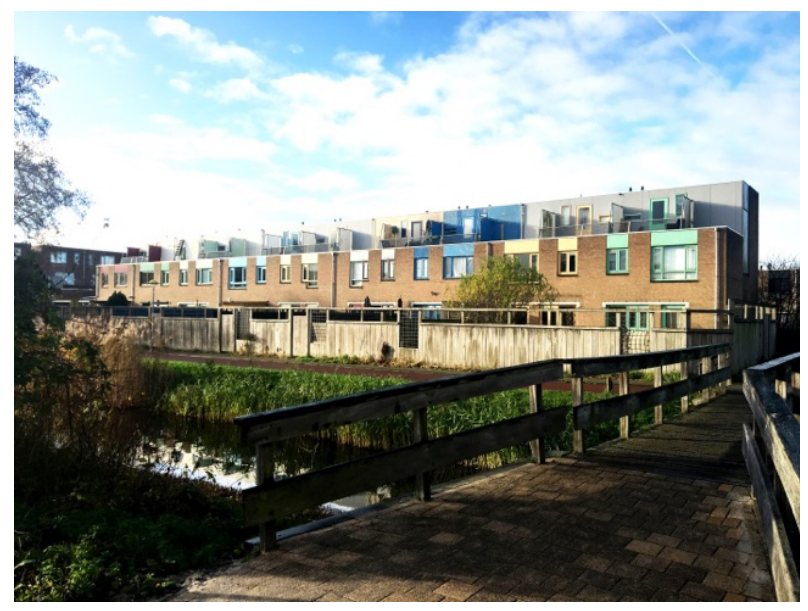

Figure 21. Waterwijk (phase 1): view of flat-roofed row houses. Source: authors.

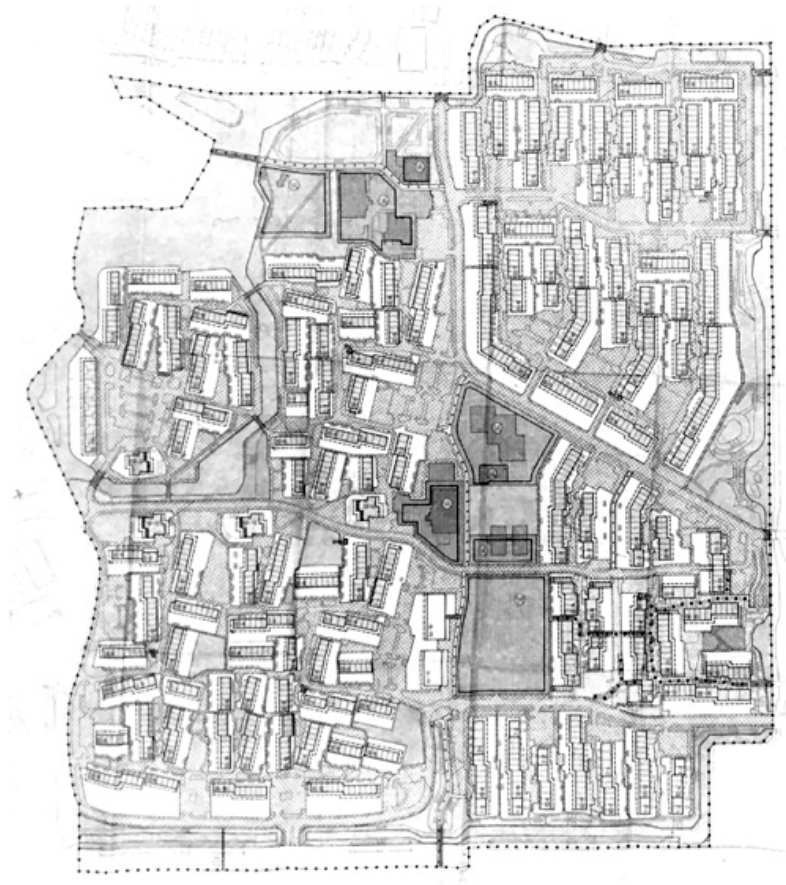

Figure 22. Boswijk's urban layout. Source: Flevolands archive.

As far as the design of this urban fabric is concerned, the inverse of the development process of Wijk 2 can be identified. In other words, there is a progressive abandonment of organic planning, seeking to return to a more rational approach based on orthogonal patterns (see Figures 20 and 22). The first houses built in Boswijk maintain roughly the previous scheme. However, the dwellings constructed later in this neighbourhood or others such as Waterwijk (Wijk 4) and parts of Schoener (Wijk 2) return to urban layouts that resemble those of Wijk 1 (see Figure 24), although some of the dwellings still show more organic and traditional features (see Figure 23). Other developments even reintroduced the flat roof characteristic of Modern Architecture (see Figure 21).

\section{Discussion and Conclusions}

This research has presented Lelystad as a significant case to illustrate the challenge of creating a New Town and explain the interaction between the search for an 'ideal shape', the realisation of the 'heroic enterprise', and the impact of political top-down decisions in the construction of a New Town, referring to the definition in the introduction. Subsequently, the article has highlighted the multiple synergies that have existed between the general planning and design of neighbourhoods. In no case are these independent processes, but in this particular case, this relationship has been especially significant. On the one hand, both have been developed under the supervision of the same public entity. On the other hand, urgent residential needs have meant that the design and construction of several neighbourhoods have been carried out ahead of the approval of the general planning, which requires long periods for its endorsement and implementation. Therefore, not only has urban planning conditioned the neighbourhood's development, but housing estates have also come to influence the execution of Lelystad's urban model. The consequence has been a gradual change in Lelystad's urban morphology. It has been noted that since 1972, neighbourhood layouts have shifted from orthogonal to more organic patterns, recovering the lost orthogonality at the end of the 1970s and especially during the 1980s. However, the morphological-urban analysis made evident that this change affects the urban form but not the general planning concept.

The main plan for Lelystad is a low-density model made up of different neighbourhoods connected to the urban infrastructure and services through large communication roads, an intermediate solution between urban large cities and small rural towns. One could conclude that the flexibility of the 1969 Structure Scheme has proven its worth. The open plan allowed to accommodate consecutive neighbourhood concepts and provided a structure for unpredictable growth.

Some of the main criticisms that the Groeikernen planning policy (including Lelystad and Almere) received during its implementation concern the monotony of housing and neighbourhoods, the unbalanced household composition and the energy waste for commuting. The urban planners of RIJP aimed for an urban model 

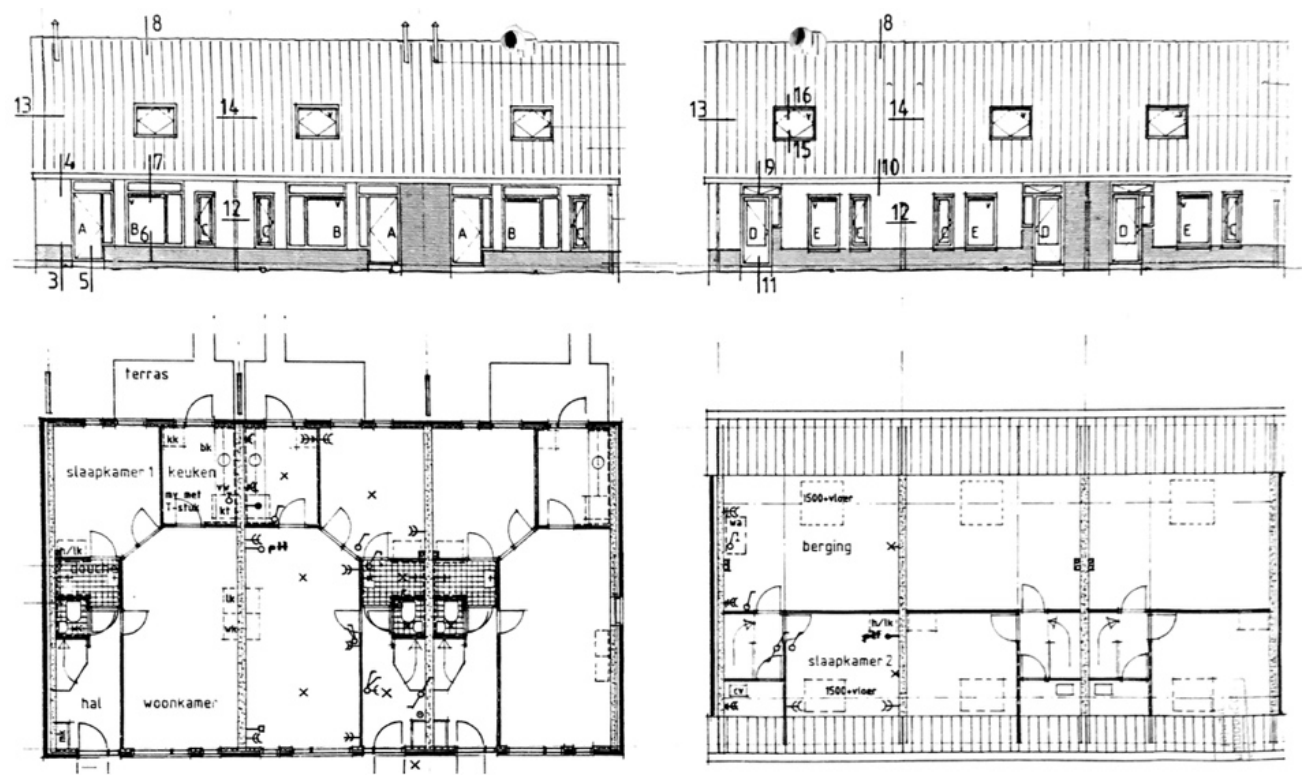

Figure 23. Schoener's house plans. Source: Flevolands archive.

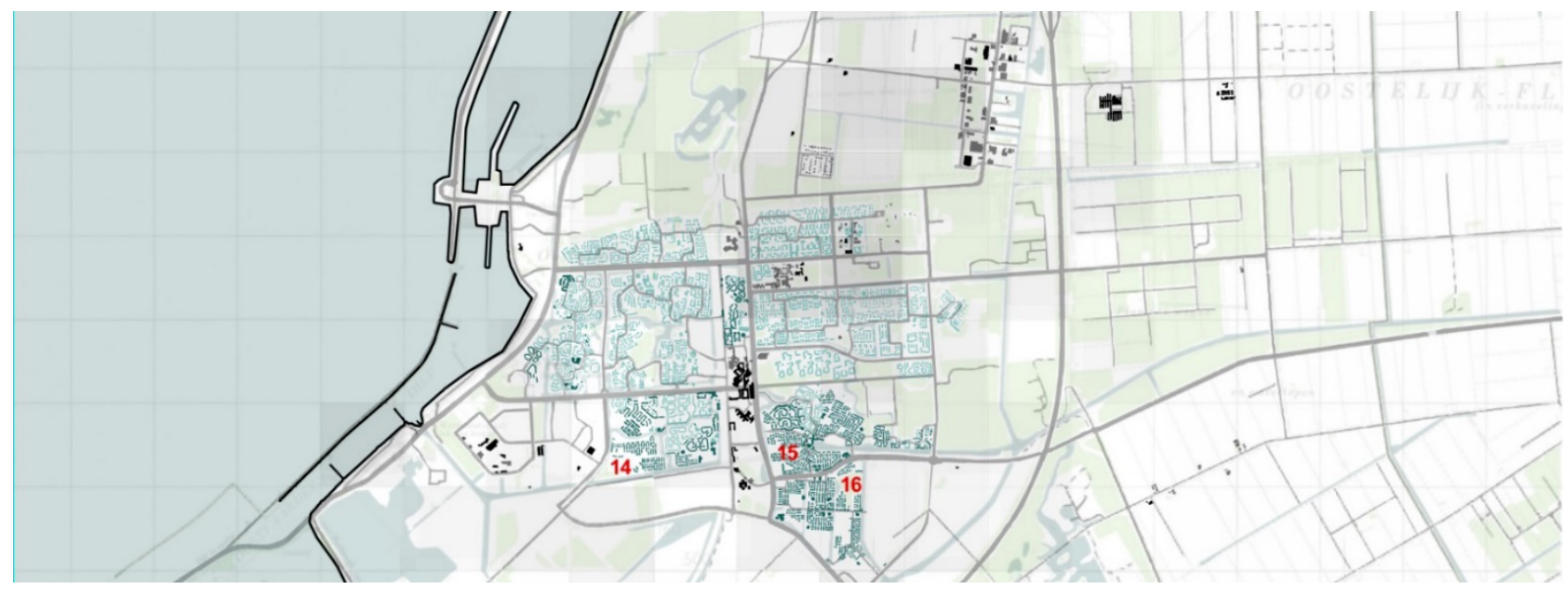

Figure 24. Neighbourhoods that were built between 1980 and 1990. Notes: (14) Schoener, (15) Boswijk and (16) Waterwijk. Source: authors.

based on single-family row houses but aspiring to a certain level of urbanity by incorporating central service areas. According to the 1978 Structure Plan, neighbourhood nodes were introduced for social and economic services and generate a certain social cohesion among citizens. However, low-density models hardly create conditions that would promote opportunities for meeting and exchange, that is, they do not ensure spatial relationships that facilitate not only social links, but also functional ones. Social cohesion implies fostering urban proximity (Tumini, Arriagada Sickinger, \& Baeriswyl Rada, 2017 , p. 41.), as well as variety and complexity of the urban environment (Monclús, 2014, p. 31). Moreover, the interaction among residents plays an important role in the establishment of social and cultural identity, as it generates an important feeling of belonging to the place and the community where they are going to live. We will never know how Van Eesteren's plan would have performed. But it is clear that the abandonment of formal urban design, in favour of flexible planning, resulted in a loose patchwork of various neighbourhoods, without a coherent and recognisable urban identity. Van Eesteren's ambition for a strong city silhouette has not been realised.

Apart from the aforementioned lack of social, cultural, and employment facilities, the Groeikernen face new challenges. They must not only respond to energy transition in 2050, but they are indicated to contribute to the housing shortage of the Randstad again. What is at risk is the loss of present qualities and characteristics, or as Pantus (2012, pp. 12-13) states: "Because of a lack of knowledge about the development of the Groeikern-phenomenon, valuable cultural-historical components that provide insight into the modernity of that time might disappear". Therefore, the current challenge would be responding to 21st-century urban chal- 
lenges, without forgetting that these cities and their neighbourhoods are the results of the modes of urban production that have characterised 20th-century Dutch urban planning and, hence, constitute a significant urban legacy to be recognised and preserved.

The study has made it possible to contextualise the case of Lelystad within a historical moment when governments take the initiative to alleviate the severe housing deficit situation existing in the whole of Europe after WWII. Lelystad's urban growth not only shares characteristics with the rest of the Dutch Groeikernenwhich were built during the same period and under comparable circumstances-but also with many other residential developments - neighbourhoods, housing estates, grossiedlungen, villes nouvelles, bairros sociais, poligonos residenciales-that were built throughout Europe. Although heterogeneous, they can be considered as part of the physical and cultural expression of a specific epoch of urban history. This fact means to resort to the already consolidated historical value in the terms included in the Washington Charter on the Conservation of Historic Towns and Urban Areas in 1987. Accordingly, the research inexorably leads to the recognition that these urban pieces constitute the particular story of urban and housing planning in this particular context, as well as to verify its social relevance.

In short, the detailed analysis that has been carried out in this work has sought to find the milestones-both positive and negative - of the urban evolution of Lelystad through the analysis of its residential neighbourhoods. This study not only aims to shed light on this process from a perspective that had not been addressed to date, but is shown as a necessary step to move forward in building the future of the city; reliable and in-depth knowledge that would make it possible to better address 21stcentury challenges while recognising the historical relevance of these neighbourhoods and, consequently, the cultural value of the resulting urban morphology.

\section{Acknowledgments}

The authors are grateful for the information provided by Batavialand's researchers and the access to original documentation provided by Het Flevolands Archief. The authors are also grateful for the financial support from Delft University of Technology and the University of Seville.

\section{Conflict of Interests}

The authors declare no conflict of interests.

\section{References}

Brouwer, P. (1997). Van stad naar stedelijkheid. Planning en planconceptie van Lelystad en Almere 1959-1974. [From city to urbanity. Planning and plan conception of Lelystad and Almere 1959-1974]. Rotterdam: NAi Uitgevers.
CBS. (2018). Population dynamics; birth, death and migration per region. Open Data CBS. Retrieved from https://opendata.cbs.nl/statline/\#/CBS/en/ dataset/37259eng/table?ts $=1559150051922$

Constandse, A. (1980). Lelystad uit de kluiten [Lelystad rapidly growing up]. Lelystad: Rijksdienst voor de IJsselmeerpolders, Ministerie van Verkeer en Waterstaat.

Constandse, A. (1989). Stedebouw als intermezzo [Urban design as an intermezzo]. Flevobericht, 1989(300), 43-50. Retrieved from http://publicaties. minienm.nl/documenten/het-blijft-mensenwerkeen-bundel-opstellen-over-het-zuiderzeepro

de Vreeze, N. (1993). Woningbouw, inspiratie \& ambities. Kwalitatieve grondslagen van de sociale woningbouw in Nederland [Housing, inspiration \& ambitions. Qualitative principles of social housing in the Netherlands] (Unpublished Doctoral dissertation). Delft: Delft University of Technology.

Faber, A. W. (1997). Werk in uitvoering: Het groeikernenbeleid, Deelstudie Vijftig jaar DGVH [Work in progress: Growth centre planning policy. Sub-study of fifty years of DVGH]. Delft: Delft University Press.

Faludi, A., \& van der Valk, A. J. (1990). De groeikernen als hoekstenen van de Nederlandse ruimtelijke planningsdoctrine [The growth centers as cornerstones of the Dutch spatial planning doctrine]. Maastricht: Van Gorcum.

Gemeente Lelystad. (1987). Statistisch jaaroverzicht 1987 [Annual statistical summary 1987]. Lelystad: Gemeente.

Geurts, A. (1993). Woningbouw in Flevoland: De rijkswoningbouwstichtingen in Lelystad, Almere en Zeewolde (1972-1992) [Housing development in Flevoland: The national housing associations in Lelystad, Almere and Zeewolde (1972-1992)]. Zutphen: Walburg.

Geurts, A. (1995). Lelystad. Stedebouwkundige ontwikkeling en vormgeving [Lelystad. Urban planning and design]. Lelystad: Uitgeverij De Twaalfde Provincie.

Heeger, H. (1992). Gedaantewisseling van naoorlogse wijken [Transformation of post-war neighbourhoods]. Stedebouw en Volkshuisvesting, 73(extra nummer I), 31-35.

Hemel, Z. (1994). Het landschap van de IJsselmeerpolders. Planning, inrichting en vormgeving [The landscape of the IJsselmeer polders. Planning, layout and design]. Rotterdam: NAi Uitgevers, EFL Stichting.

International New Town Institute. (n.d.). What is a New Town? New Town Institute. Retrieved from http:// www.newtowninstitute.org/spip.php?rubrique1

Maas, T. (2012). 35 icons of Dutch spatial planning. Den Haag: Ministry of Infrastructure and the Environment.

Monclús, J. (2014). Urban regeneration. Proposals for San Pablo neighborhood. Zaragoza: Ayuntamiento de Zaragozaa and Prensas Universitarias de Zaragoza.

National Office for the IJsselmeerpolders. (1971). Atlas voor Flevoland 1971 [Atlas for Flevoland 1971]. 
Zwolle: Rijksdienst voor de IJsselmeerpolders.

National Office for the IJsselmeerpolders. (1975). Lelystad 1973-1974. Lelystad: Rijksdienst voor de IJsselmeerpolders.

Nio, I. H. L. (2016). Moderniteit en suburbaniteit in de nieuwe stad. Almere, Cergy-Pontoise, Milton Keynes [Modernity and suburbanity in the new city. Almere, Cergy-Pontoise, Milton Keynes]. Amsterdam: Universiteit van Amsterdam.

Pantus, W. J. (2012). Groeikernen in Nederland [Growth centers in the Netherlands]. Utrecht: Uitgeverij Matrijs.

Somer, K. (2007). The functional city: The CIAM and Cornelis van Eesteren, 1928-1960. Rotterdam: NAi Uitgevers.

Tumini, I., Arriagada Sickinger, C., \& Baeriswyl Rada, S. (2017). Model to integrate resiliente and sustainability into urban planning. In P. Mercader-Moyano (Ed.), Sustainable development and renovation in architec- ture, urbanism and engineering. Cham: Springer. van der Wal, C. (1997). In praise of common sense. Planning the ordinary. A physical planning history of the new towns in the IJsselmeerpolders. Rotterdam: Uitgeverij 010 .

van Heuvel, W. J. (1992). Structuralisme in de Nederlandse architectuur [Structuralism in Dutch architecture]. Rotterdam: Uitgeverij 010.

van Woensel, J. T. W. H. (1995). Woningbouwvereniging Lelystad: 1977-1993 [Lelystad housing association: 1977-1993]. Lelystad: Uitgeverij De Twaalfde Provincie.

Wagenaar, C. (2015). Town planning in the Netherlands since 1800: Responses to enlightenment ideas and geopolitical realities. Rotterdam: NAi Uitgevers.

Werkcommissie Westen des Lands. (1958). De Ontwikkeling van het Westen des Lands [The development of the west of the country]. Den Haag: Staatsdrukkerij Uitgeversbedrijf.

\section{About the Authors}

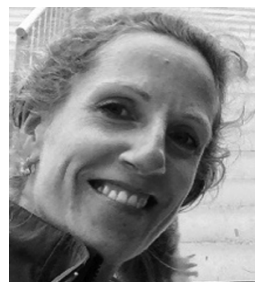

Lidwine Spoormans is a Researcher and Lecturer of Heritage \& Design at Delft University of Technology (Netherlands) since 2011. After a career as a practising architect, working on large scale housing and renovation projects, she returned to Delft Technical University. Her research fields include housing renovation, building systems, intervention methods, young heritage. She organised a series of graduation studios on the topic of housing transformation and she is member of the Management Committee of the COST Action on European Middle Class Mass Housing. Currently, she is working on the exploration of architectural values of post-war New Towns. In 2017 she launched the digital platform www.love80sarchitecture.nl

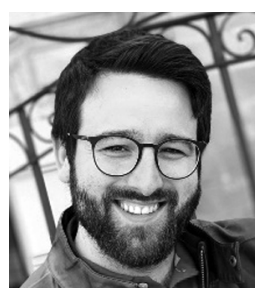

Daniel Navas-Carrillo is a Pre-doctoral Researcher at the Urbanism and Territory Planning Department of the University of Seville (Spain) since 2016. He holds an MSc in Innovation in Architecture (University of Seville, 2016) and an MSc in Heritage and Architecture (University of Seville, 2017). His research aims to analyse the urban growth experienced in the third quarter of the 20th century in medium-sized cities from a heritage perspective. He has received several prizes such as the Urbanism and Architecture Biennale Research Award (2016) and Young Researcher Award TecnoHeritage (2019).

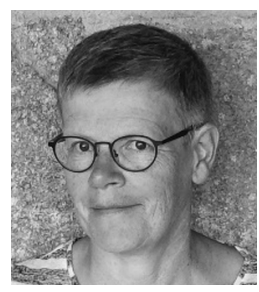

Hielkje Zijlstra is an Associate Professor of Heritage \& Design at Delft University of Technology (Netherlands) since 2005. She holds a PhD in Architecture and Building Technology in 2006: Building in the Netherlands 1940-1970. Research field analyses of buildings, re-use, and policymaking for the sustainable conservation of built heritage. She is currently project leader of the KaDEr research project. From 2015-2018, she was section leader of Heritage \& Architecture. Since 2001, she has been involved in many Master and Doctorate education projects and programmes. Secretary of Docomomo-NL (2006-2008), Expert Committee Urban Development COST (2006-20015), Reviewer European Science Foundation (ESF), member of the board of studies (Faculty of Architecture TUD), guest Professor at the Kyoto University of Technology. Her motto is: creating opportunities for young people to excel.

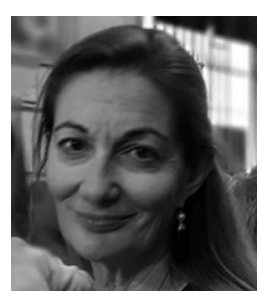

Teresa Pérez-Cano is a full-time Professor at the Urbanism and Territory Planning Department of the University of Seville (Spain) since 1995. Permanently collaborating with several Master and Doctorate programmes, she has been the director of more than 28 doctoral theses. Co-founder and director of the research group HUM-700 Heritage and Urban and Territorial Development in Andalusia. Focused on urban planning preservation, the group has conducted several types of research, urban plans, and professional advisory on classed buildings, monuments, historic centres, and landscapes. She is currently leading an R\&D project on medium-sized cities in Andalusia. 